Newfoundland and Labrador Studies

\title{
Ted Russell. The Smokeroom on the Kyle
}

\section{Morgon Mills}

Volume 34, Number 1, 2019

URI: https://id.erudit.org/iderudit/1072444ar

DOI: https://doi.org/10.7202/1072444ar

See table of contents

Publisher(s)

Faculty of Arts, Memorial University

ISSN

1719-1726 (print)

1715-1430 (digital)

Explore this journal

Cite this review

Mills, M. (2019). Review of [Ted Russell. The Smokeroom on the Kyle].

Newfoundland and Labrador Studies, 34(1), 182-184.

https://doi.org/10.7202/1072444ar viewed online.

https://apropos.erudit.org/en/users/policy-on-use/ 
Ted Russell. The Smokeroom on the Kyle. St. John's: Pennywell Books, 2017. ISBN 978-1-7711-7607-1

Famous poems often serve as eponyms for collections, but in Newfoundland and Labrador, Ted Russell's "The Smokeroom on the Kyle" is loved well enough and widely enough to merit a volume of its own. Its two voices are those of Grampa Walcott and an unnamed narrator readers may recognize as Uncle Mose, a storytelling persona created by Russell to chronicle life in Pigeon Inlet, a fictional community based on the outports of northeastern Newfoundland. In "Smokeroom," Grampa regales Kyle passengers with a story of squid clinging to one another in a miles-long chain as local fishermen haul them in hand over hand.

Like all of Russell's Pigeon Inlet material, most of which was developed for CBC Radio in the 1950s and 1960s, "Smokeroom" relies for its success on Russell's ear for language, eye for detail, and smooth execution of the conventions of his chosen form. The poem's regional appeal and cultural significance come from the authenticity of its turn of phrase ("me son," "cocks and hens") and from the loving attention it gives to its setting. Both qualities celebrate the lifeways and experiences of the poem's Newfoundland audience.

At the same time, the verse employs a time-tested aesthetic that resonates anywhere. The now book-length poem is written in four-line stanzas, all in rhyming heptameter couplets, with the first stanza repeated at the end: a form used most famously in Canada by Robert Service in "The Cremation of Sam McGee." It is meant for recitation, and the rhythmic narrative causes readers like me to rush through it headlong, though a well-practised recitation by the writer's son Kelly Russell runs over five minutes.

Like the form, the central story is basically conventional. According to a 2005 biography by Russell's daughter Elizabeth Miller, "very few, if any, of Ted's tales were original" (207), and most, including the story of the squid, followed traditional folk motifs. The squid story in particular was evidently gathered "at a party in St. John's during the 
thirties [from] Allan Bishop, who in turn had heard it many years before from an old gentleman in Joe Batt's Arm"(208), but in all likelihood even then it had already been told for generations, in one form or another.

As a cultural text in its own right, "Smokeroom" is worth republishing, but the real substance of Pennywell's new edition is in Tara Fleming's illustrations. Fleming hasn't merely illustrated the poem, but transformed it into a different sort of text. Now a children's book, "Smokeroom" is still largely oral, in the sense that it will mostly be read aloud by parents, but it has assumed visual and tactile dimensions as well. It has become a physical object, rather than a basis for performance.

In an NTV features segment, Kelly Russell noted that his father never "imagined that it would be a children's story," and indeed the feel is not exactly right, especially in 2017, when "baccy smoke from twenty pipes," for example, requires a bit of explanation. Nevertheless, the poem's jolly sound and simple narrative are well suited for children. In the same feature, Fleming admits to feeling a "responsibility to get [the illustrations] right," because of the poem's celebrated status. Curiously, however, her work succeeds precisely because she does not insist on getting her artwork scrupulously correct. Despite the specificity of the setting, Fleming's illustrations belong to no particular time, and without being anachronistic, she wisely avoids fixation on period detail. The characters look like they could equally plausibly inhabit the time of the poem's narration in the 1950s, the time of the squid story in 1888, or even our own time - as far in the poem's future as the squid are in its past. The images' physical environments, too, are universalized and accessible. Overall, Fleming draws more on the story's emotional energy than its regionalism, capturing the thrill of the yarn in bright colours and a contemporary style.

Repackaging old favourites is a process of value-addition as much as anything else. In that sense, the extension of Russell's Uncle Mose material to children's story-times is certainly a meaningful achievement, but more might easily have been done to add value. The included map and simple glossary provide some supplemental information for 
understanding the text, for example, but children, regional outsiders, and future generations are more likely to be baffled by contextual nuance than by individual terms and place names. More importantly, even a brief critical introduction or postscript could position "Smokeroom" in its historical context and further advance readers' interest in Russell's work. Without that context, the book is not quite the doorway into Pigeon Inlet that it might have been.

A somewhat similar adaptation project is carried out in Geoff Butler's 2016 illustrated version of The Ode to Labrador. Butler expands another short, much-loved piece of verse into book form, with a focus on painted illustrations. In his case, however, Robin McGrath provides substantial supplementary text. In a children's book that might be an encumbrance, but maybe a happy medium could have been found for this publication of The Smokeroom on the Kyle.

\section{References}

Butler, Geoff. The Illustrated Ode to Labrador. St. John's: Creative Book Publishing, 2016.

Miller, Elizabeth Russell. Uncle Mose: The Life of Ted Russell, 2nd ed. St. John's: Flanker Press, 2005.

NTV. Backstage Pass with Amanda Mews. Interview with Kelly Russell and Tara Fleming. 19 July 2017. ntv.ca/features/backstage-pass/. Accessed 12 Mar. 2018.

Morgon Mills

Memorial University of Newfoundland 